\title{
An Analysis on High School Students' Perceptions of Physics Courses in Terms of Gender (A Sample from Turkey)
}

\author{
Medine Baran \\ Correspondence: Medine Baran, Department of Physics Education, Dicle University, Turkey. \\ Received: December 12, 2015 Accepted: January 21, 2016 Online Published: February 2, 2016 \\ doi:10.11114/jets.v4i3.1243 \\ URL: http://dx.doi.org/10.11114/jets.v4i3.1243
}

\begin{abstract}
This study was carried out to determine high school students' perceptions of the courses of Physics and the factors influential on their perceptions with respect to gender. The research sample included 154 high school students (F:78; M:76). In the study, as the data collection tool, a structured interview form was used. The data collected in the study were analyzed with frequency analysis, Chi-square and content analysis. As a result of the study, it was found that the male students were found themselves more successful in the courses of physics and that they experienced less difficulty with the courses. It was also revealed that there were no differences between female and male students' views related to physics entertaining, importance and permanency yet difficult in terms of mathematical calculations. In general, the students had bias regarding physics and stated that the current course of physics was not efficient and that interactive and practical methods should be put into practice. According to the results, the male students demonstrated more positive attitudes than the female students. In the light of the findings obtained, it could be stated that current high school applications in the courses of physics should be revised by authorities.
\end{abstract}

Keywords: courses of physics, perceptions, gender, high school students

\section{Introduction}

Physics has a vital role in understanding the world, and there are important contributions of physicists to nations' welfare as well as to their economic development. Many professions and industries require physicists to have the necessary knowledge and problem-solving skills. In order to survive in the current rapidly-changing technological world, all countries are supposed to have a population well-educated in physics (International Union of Pure and Applied Physics [IUPAP], 2002 Cited in Buabeng et. al., 2012). In many countries throughout the world, one of the most important issues related to the science of physics is to understand this science and to advance in physics. However, in many studies, it was indicated that performance in science is not encouraging (Aina and Philip, 2013; Aina, 2013). Especially in physics, the problem is prominent. Bamidele (2001) reported that students' lack of interest in physics is because of their perception that physics is a difficult subject. Also, the negative perceptions of the students have influence on their performance in Physics course.

In line with the effective contribution of the science of physics and with the changing and developing technologies, women's social roles change as well. Especially when compared to the previous years, women could be said to be more active in science as well as in all other fields though not at the desired level. In this respect, in recent years, a number of studies have been conducted on women's interactions with physics, an important component of science (Madsen et. al., 2013; Homer et.al., 2013; Bates et. al., 2012; Mallow, 2010). The causes of this increase in the number of studies include the low number of working women in scientific fields like physics in many parts of the world and female students' being less successful or interested in learning environments than their male peers (Bayraktar, 1999). Similarly, Kost- Smith and colleagues (2010) reported that physics was the field least represented by women though it changes in time. Whitten and colleagues (2003) defined men's dominance in fields of physics as a puzzle and stated that there was an increase in women's appearance in these fields between 1992 and 1998, though not sufficient. In addition, studies (Kost et. al, 2009; Visser, 2007; Keeves \& Kotte, 1992) revealed that male students more liked the courses of physics more than their female peers. Özgün Koca and Şen (2011) reported in their study that male students liked Physics courses more than female students. Also, it was reported in other studies that female students were less interested thus less successful in physics than male students (Kessel et.al, 2006). Parallel to this, Saleh (2014) and Veloo and colleagues (2015) pointed out that female students experienced a higher level of difficulty understanding physics than the male students. When other studies examining the reasons for these differences are examined, it is seen that these differences 
could have resulted from different biological brain structures of male and female students in the past (Jovanavic and Dreves, 1994 cited in Özay at.al., 2003). On the other hand, research data revealed that there is no difference between the intelligence of male and female students. Female students have good performance at school and in university exams (McKenna et. al, 2002). Moreover, it is thought that due to recent technologies, the brain structures of women and men can not lead to such differences. When this situation is viewed from a different perspective, it could be stated that the socio-cultural structure of the society which individuals belong to is important. In addition, it could also be stated that men's active state in social life and women's roles in the society could lead to gender-based differences in the fields of science. Besides this, this is claimed by Unesco (2007) to a general problem throughout the world, and it is pointed out that women constitute more than $50 \%$ of the world' population and that they do not exist at the desired level in scientific fields, though. It is important to taken into account not only the results of studies conducted to overcome this deficiency of women in related fields but also the suggestions put forward in line with the results of these studies. In this respect, the present study shed light on this problem, raised important issues related to students' perceptions regarding the courses of physics with respect to the variable of gender and put forward related suggestions. The study thus focused on the factors influential on students' perceptions. Therefore, the male and female students' self-reported perceptions regarding the courses of physics were examined, and they were asked to state their suggestions. With the present study, it is believed that the results will help decrease the gender-based differences in the fields of science. In addition, the fact that there was no other study carried out in the region where the present study was conducted makes this study important. Parallel to this, the findings obtained in the present study are thought to fill the gap in related literature.

In the study, the following research questions were directed:

1-Are there any significant differences between the students' perceptions regarding the courses of physics with respect to the variable of gender?

2- Are there any similarities and differences between the reasons regarding the male and female students' perceptions?

\section{Method}

\subsection{Research Model}

In the present study, the qualitative research approach was used. Qualitative research is based on examining a research problem in an interpretive manner from an interdisciplinary holistic perspective (Karataş, 2015).

\subsection{Participants}

The study group included $1^{\text {st }}, 2^{\text {nd }}, 3^{\text {rd }}$ and $4^{\text {th }}$ grade students attending four high schools in the city of Diyarbakir in Turkey in the academic year of 2014-2015. The research sample was made up of a total of 154 high school students, 76 of whom were female and 78 of whom were male. In the study, the participants were determined depending on their convenience. Convenience sample refers to accessibility of the participants as well as to their convenience for evaluation (Cox, 2015).

\subsection{Data Collection Tools}

In the study, before the development of the structured interview form to collect the research data, a pilot study was carried out. The students from different high schools were asked to state their emotions and thoughts regarding the courses of physics. In the light of the students' views they reported in writing, the questions in the interview form were prepared. Experts from the fields of field education, measurement/evaluation and Turkish language teaching were asked for their views about this draft form developed by the researcher. As a result, several changes were made in line with the experts' suggestions, and the interview form made up of six clear and easy-to-understand open-ended questions that would serve the research purpose was obtained. In this way, the validity and reliability of the data collection tool were achieved.

\subsection{Data Collection and Analysis}

Before the application, the National Education Provincial Directory was asked for the necessary consents both for the pilot study and for the study itself. In the study, the researcher contacted individually with the administrators as well as with the teachers working at the schools where the study would be conducted. The students were allocated one class hour to respond to the questions in the interview form. In the study, a total of 180 interview forms were used, yet 26 of them were not included in the data analysis process as they were not filled out seriously. In the present study, the data were collected with the structured interview technique, one of qualitative research methods. For the purpose of determining the factors influential on the students' perceptions regarding the courses of physics, a six-question interview form was used. The data gathered based on the statements found in the interview form were analyzed with content analysis and with frequency analysis and Chi-square independence test found in SPSS 20 package software. 
Hsieh and Shannon, (2005) reported that "Content analysis is one of numerous research methods used to analyze text data. Content analysis is defined as a research method for the subjective interpretation of the content of text data through the systematic classification process of coding and identifying themes or patterns".

In this study content analysis of the research data collected in the study was carried out both by the researcher and by a faculty member via coding and identifying themes processes. The analyses conducted by different researchers were compared. With these comparisons, the reliability of the study was tested. While testing the reliability of the study, the reliability calculation method suggested by Miles and Huberman (1994) (Reliability=consensus)/(consensus+disagreement). As a result of the calculation, the reliability of the study was found to be $85 \%$. Miles and Huberman (1994) stated that reliability result high than $70 \%$ is sufficient for the reliability of a study. Thus, the analysis of the data collected in the study was found reliable in the present study.

\section{Results}

The data collected in the study were analyzed with content analysis method. The results of the analysis revealed such themes and codes as finding the courses of physics difficult, finding the courses of physics in terms of mathematical calculations, considering oneself to be successful in physics, finding the courses of physics entertaining, views about importance of the physics courses and permanency of their post-school physics knowledge. This part of the study presents not only the related Chi-square independence test results with respect to the variable of gender but also the codes and themes regarding their causes.

Table 1 demonstrates the Chi-square test results related to the male and female students' finding the courses of physics difficult.

Table 1. Students' finding physics difficult with respect to gender

\begin{tabular}{|c|c|c|c|c|c|c|}
\hline \multirow[t]{2}{*}{ Gender } & & \multicolumn{3}{|c|}{$\begin{array}{l}\text { I generally find physics courses } \\
\text { difficult }\end{array}$} & \multirow[t]{2}{*}{ Total } & \multirow[t]{2}{*}{$\mathrm{P}$} \\
\hline & & Yes & No & Partly & & \\
\hline & \multirow{2}{*}{ Female } & 57 & 6 & 15 & 78 & \multirow{6}{*}{.004} \\
\hline & & $59 \%$ & $23 \%$ & $47 \%$ & $51 \%$ & \\
\hline & \multirow{2}{*}{ Male } & 39 & 20 & 17 & 76 & \\
\hline & & $41 \%$ & $76 \%$ & $53 \%$ & $49 \%$ & \\
\hline \multirow{2}{*}{\multicolumn{2}{|c|}{ Total }} & 96 & 26 & 32 & 154 & \\
\hline & & $100 \%$ & $100 \%$ & $100 \%$ & $100 \%$ & \\
\hline
\end{tabular}

When Table 1 is examined, high school students' perception of physics as a difficult subject depends in part on the gender of the student; chi-square analyses of independence indicate that females deem the discipline to be harder than their male peers; $\mathrm{X}^{2}(\mathrm{df}: 1 \mathrm{~N}=154)=11.04, \mathrm{p}<.05$.

Table 2 presents the results of analysis regarding the students' finding the courses of physics difficult in terms of mathematical calculations.

Table 2. Students' finding physics mathematically difficult with respect to gender

\begin{tabular}{|c|c|c|c|c|c|}
\hline \multirow[t]{2}{*}{ Gender } & & \multicolumn{2}{|c|}{ Mathematically difficult } & \multirow[t]{2}{*}{ Total } & \multirow[t]{2}{*}{$P$} \\
\hline & & Yes & No & & \\
\hline & \multirow{2}{*}{ Female } & 29 & 49 & 78 & \multirow{6}{*}{.148} \\
\hline & & $59 \%$ & $46 \%$ & $50 \%$ & \\
\hline & \multirow{2}{*}{ Male } & 20 & 56 & 76 & \\
\hline & & $41 \%$ & $53 \%$ & $49 \%$ & \\
\hline \multirow{2}{*}{ Total } & & 49 & 105 & 154 & \\
\hline & & $100 \%$ & $100 \%$ & $100 \%$ & \\
\hline
\end{tabular}

When Table 2 is examined, chi-square analyses of independence indicate that the relationship between gender and perception of the courses of physics as a difficult subject mathematically was not significant; $X^{2}(d f=1 N=154)=2.094$, $\mathrm{p}>.05$.

Table 3 presents the results of analysis regarding the students' considering themselves to be successful in the courses of physics in terms of gender. 
Table 3. Students' considering themselves to be successful in physics with respect to gender

\begin{tabular}{|c|c|c|c|c|c|c|}
\hline \multirow[t]{2}{*}{ Gender } & & \multicolumn{3}{|c|}{ I find myself successful } & \multirow[t]{2}{*}{ Total } & \multirow[t]{2}{*}{$\mathrm{P}$} \\
\hline & & Yes & $\mathrm{No}$ & Moderate & & \\
\hline & \multirow{2}{*}{ Female } & 8 & 46 & 24 & 78 & \multirow{6}{*}{.001} \\
\hline & & $23 \%$ & $60 \%$ & $54 \%$ & $51 \%$ & \\
\hline & \multirow{2}{*}{ Male } & 26 & 30 & 20 & 76 & \\
\hline & & $76 \%$ & $39 \%$ & $45 \%$ & $49 \%$ & \\
\hline \multirow{2}{*}{ Total } & & 34 & 76 & 44 & 154 & \\
\hline & & $100 \%$ & $100 \%$ & $100 \%$ & $100 \%$ & \\
\hline
\end{tabular}

When Table 3 is examined, according to chi-square analyses of independence, it could be stated that the male students considered themselves to be more successful in the courses of physics when compared to the female students ; $\mathrm{X}^{2}$ (df: 2 $\mathrm{N}=154)=13.238, \mathrm{p}<.05$.

Table 4 demonstrates the Chi-square test results related to the male and female students' views about importance of the courses of physics.

Table 4. Students' views of importance of physics courses with respect to gender

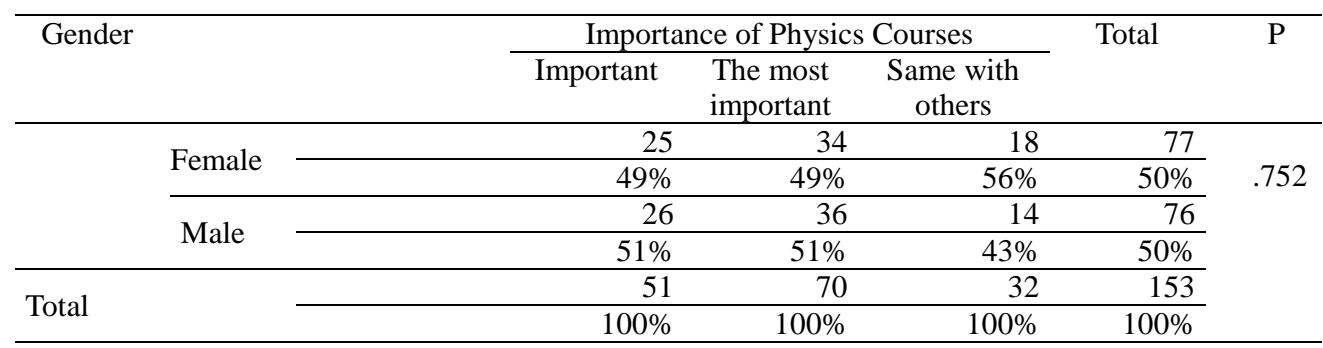

In Table 4, chi-square analyses of independence indicate that the relationship between gender and perception of the importance of courses of physics was not significant; $\mathrm{X}^{2}(\mathrm{df}: 2 \mathrm{~N}=153)=.570, \mathrm{P}>.05$.

Table 5 presents the results of analysis regarding the students' views about the permanency of their physics knowledge with respect to gender.

Table 5. Distribution of the students' views about the permanency of their post-school physics knowledge with respect to gender

\begin{tabular}{|c|c|c|c|c|c|}
\hline \multirow[t]{2}{*}{ Gender } & & \multicolumn{2}{|c|}{ It is permanent } & \multirow[t]{2}{*}{ Total } & \multirow[t]{2}{*}{$\mathrm{P}$} \\
\hline & & Yes & No & & \\
\hline & \multirow{2}{*}{ Female } & 19 & 50 & 69 & \multirow{5}{*}{.254} \\
\hline & & $40 \%$ & $50 \%$ & $47 \%$ & \\
\hline & \multirow{2}{*}{ Male } & 28 & 49 & 77 & \\
\hline & & $59 \%$ & $49 \%$ & $53 \%$ & \\
\hline \multirow{2}{*}{ Total } & & 47 & 99 & 146 & \\
\hline & & $100 \%$ & $100 \%$ & $100 \%$ & \\
\hline
\end{tabular}

In Table 5, chi-square analyses of independence indicate that there was no significant relationship between gender and the perceptions of the permanency of their physics knowledge; $\mathrm{X}^{2}(\mathrm{df}: 1 \mathrm{~N}=146)=1.299, \mathrm{P}>.05$.

Table 6 presents the results of analysis regarding the students' finding the courses of physics entertaining.

Table 6. Distribution of students' finding physics entertaining with respect to gender

\begin{tabular}{|c|c|c|c|c|c|c|}
\hline \multirow[t]{2}{*}{ Gender } & & \multicolumn{3}{|c|}{ I find physics entertaining } & \multirow[t]{2}{*}{ Total } & \multirow[t]{2}{*}{$\mathrm{P}$} \\
\hline & & Yes & No & Partly & & \\
\hline & \multirow{2}{*}{ Female } & 18 & 34 & 17 & 69 & \multirow{6}{*}{.212} \\
\hline & & $37 \%$ & $50 \%$ & $56 \%$ & $47 \%$ & \\
\hline & \multirow{2}{*}{ Male } & 30 & 34 & 13 & 77 & \\
\hline & & $62 \%$ & $50 \%$ & $43 \%$ & $53 \%$ & \\
\hline \multirow{2}{*}{ Total } & & 48 & 68 & 30 & 146 & \\
\hline & & $100 \%$ & $100 \%$ & $100 \%$ & $100 \%$ & \\
\hline
\end{tabular}

When Table 6 is examined, it is seen that most of the participants did not find the courses of physics entertaining and chi-square analyses of independence indicate that there was no significant relationship between gender and the perceptions of the courses of physics entertaining; $\mathrm{X}^{2}(\mathrm{df}: 2 \mathrm{~N}=146)=3.104, \mathrm{P}>.05$. 
Table 7 presents the results of analysis regarding the factors influential on the female students in the courses of physics.

Table 7. Female students' views about the factors influential on them in physics courses

\section{Theme 1: The Students}

I like my physics courses.

I like reasoning.

I am a curious person, and I like doing research.

I think it is a different experience.

I study a lot, and I am a succesfull

I constantly solve questions.

I listen to the teacher in class.

I like the mathematical part of physics.

I hate it.

I don't like it, and I can't do it. I can't learn or understand.

When I study, it is usually all in vain. I have a limited capacity for it.

I experience family pressure.

I have a bias.

I easily forget what I have learnt.

I can't memorize.

I solve few questions.

I don't understand immediately.

I have difficulty in mathematical calculations.

I don't take notes.

I can't transfer my knowledge into practice.

I don't have self-confidence.

\section{Theme 4: Suggestions}

The length of lessons should be shortened
Theme 2: The Teacher of the Physics Courses

f

16 The teacher is not satisfactory. 17

8 The teacher teaches the lesson in an entertaining and 15 effective manner.

7 The teacher's way of teaching is not good or effective. 18

5 S/he teaches quite slowly and does not know how to 8 teach.

7 S/he doesn't have the necessary skills and knowledge. 13

10 Sometimes, s/he teaches quite fast. 6

12 S/he confuses my mind. 9

19 S/he doesn't teach in accordance with our level of 7 knowledge

13 S/he doesn't have control over the class. $\quad 14$

5 S/he interacts badly with the students.

\section{Theme 3: Physics Courses}

8 It is entertaining, important and attention-drawing. 16

16 It explains the nature, gives new information and 24 includes examples from daily life.

17 It is useful, and it facilitates life. 13

31 It is quite complicated. 18

18 It is boring and too abstract. $\quad 12$

15 It covers too many subjects $\quad 7$

12 There are many formulas 20

17 Theme 4: Suggestions

13 Visuals should be used; experiments should be 21 conducted

16 The teacher should be able to chat and make jokes 12 The teacher should help students get rid of their bias 18

14 Teacher-student interaction should be established 25

12 We should work harder; we should visualize in our 7 mind.

The teacher should teach the lessons in an entertaining 19 manner.

15 The lessons should be associated with daily life events 30 
Table 8 presents the results of content analysis regarding the factors influential on the male students in the courses of physics.

Table 8. Results of content analysis regarding the factors influential on the male students in physics courses

\begin{tabular}{|c|c|c|c|}
\hline Theme 1: The Students & f & Theme 2: The Teacher of the Course & f \\
\hline I broke down my prejudices. & 15 & His/her way of teaching is wrong. & 12 \\
\hline I like the mathematical part. & 20 & S/he lacks the necessary qualifications. & 14 \\
\hline I am a curious student. & 12 & S/he teaches fast. & 8 \\
\hline $\begin{array}{l}\text { I want to find answers to the } \\
\text { questions in my mind about physics. }\end{array}$ & 8 & $\mathrm{~S} / \mathrm{he}$ is not a conscious teacher. & 11 \\
\hline I study a lot. & 10 & The teacher helps me. & 10 \\
\hline I do research. & 9 & S/he teaches well. & 8 \\
\hline $\begin{array}{l}\text { I am a successful and clever } \\
\text { student. }\end{array}$ & 21 & S/he regards teaching just as a duty. & 7 \\
\hline I have self-confidence. & 19 & $\mathrm{~S} / \mathrm{he}$ is narrow-minded. & 3 \\
\hline I solve a lot of questions. & 12 & Theme 3: Physics Courses & \\
\hline I like the courses of physics. & 27 & Mathematical calculations are difficult. & 14 \\
\hline I don't study. & 8 & $\begin{array}{l}\text { Some subjects are difficult, and they require } \\
\text { memorization. }\end{array}$ & 6 \\
\hline $\begin{array}{l}\text { I can't establish connections between } \\
\text { concepts }\end{array}$ & 10 & It has connection with daily life. & 27 \\
\hline $\begin{array}{l}\text { I don't have enough related } \\
\text { background knowledge. }\end{array}$ & 24 & $\begin{array}{l}\text { It is quite important in terms of the university } \\
\text { placement exam. }\end{array}$ & 8 \\
\hline I don't understand. & 14 & It includes the secret of the universe. & 5 \\
\hline I don't have self-confidence. & 10 & It is & 18 \\
\hline I have prejudices. & 31 & It is easy and exciting. & 16 \\
\hline $\begin{array}{l}\text { I have difficulty doing } \\
\text { interpretations. }\end{array}$ & 6 & It is & 13 \\
\hline I have low level of motivation. & 11 & It is & 6 \\
\hline I can't learn. & 13 & It is & 14 \\
\hline I don't like it. & 16 & re too many & 8 \\
\hline Theme 4: Learning environment & & The curriculum is intensive. & 4 \\
\hline $\begin{array}{l}\text { My friends have negative effects on } \\
\text { me. }\end{array}$ & 16 & Theme 5: Suggestions & \\
\hline We don't do any experiments. & 21 & The & 16 \\
\hline$y$ in class. & 18 & ries. & 31 \\
\hline I have adaptation problems. & 15 & $\begin{array}{l}\text { They should allow learning by } \\
\text { doing-living. }\end{array}$ & 30 \\
\hline Theme & & Experienced teachers should teach the lessons. & 7 \\
\hline The duration of lessons could be & 14 & They should give examples from daily life. & 32 \\
\hline
\end{tabular}
shortened.

According to Table 7 and Table 8 above, the themes the students reported their views mostly about did not generally change on the basis of the variable of gender; however, the male students, different from the female ones, stated that the learning environment had negative effects on their perceptions regarding the courses of physics. Not only the female students but also the male students participating in the study stated that they did not have good background knowledge about physics and that they had prejudices regarding physics. In addition, some of the female students reported the negative factors to include individual differences, family pressure, limited capacity, easily forgetting and understanding physics lessons late while the male students mentioned the positive effects of intelligence and self-confidence and the negative effects of adaptation problems. Some of the male students participating in the study stated that they liked the courses of mathematics and that there was positive influence of the mathematical part of physics. Also, the students in both groups focused not only on the mathematical aspect of physics but also its connection with daily life. The male and female students reported that that student-centered applications like laboratory and learning by doing and living were necessary to make physics lessons entertaining and interesting. Besides, an important number of the male students and the female students focused on more qualified teachers. In addition, some of the students stated that the duration of lessons should be shortened, physics should be taught in laboratories and connected with daily life to solve such problems.

\section{Discussion}

According to the results of the analyses conducted in the study, female students found the courses of physics more difficult and considered themselves to be less successful when compared to the male students. The results of content analysis conducted in the present study revealed that both groups of students had bias regarding the courses of physics. In this study, it was found that an important number of the female students did not listen to physics lessons and that they 
did not take notes. As a supporter claim to this findings, Mujtaba and Reiss, (2012) stated that the attendance of the female students effect their perceptions of physics. According to Buabeng (2012), female students' lack of interest physics had negative influence on their attendance in physics classes. Besides its negative influence on class attendance, lack of interest is also high likely to cause students to fail to understand physics lessons. Therefore, they will naturally find the courses of physics difficult to understand and achieve. This may lead to the development of bias regarding the courses. For this reason, it is thought that together with lack of attendance in class, students might develop the feeling of failure in the courses. In addition, it was a striking result that the female students reported such factors as limited capacity, family pressure to have negative influence on their success in the courses of physics. Bamidele (2001) examined success in physics with respect to the variable of gender and found a significant difference in favor of the male students. According to the researcher, this result was because female students believe they have a lower level of capacity in scientific fields than male students. In another study, Schunk and Meece (2005) reported that families' perceptions had important influence students' efficacy beliefs. Similarly, review of literature carried out by Desforges and Abouchaar (2003) revealed that the variable of family plays an important role in students' success. In addition, in the present study, it was found that the some of female students easily forget what they had learnt; that they understood physics lessons late. Therefore, the female students participating in this study found could be said to find the courses of physics difficult. In the study, no important difference was found at all in relation to the codes regarding the courses themes when the male and female students participating in the study expressed the reasons for their success and for the related difficulties they experienced. Based on these findings obtained in the study, the important differences between the both groups of students existed in the factors related to personal factors and to the learning environment factors. The cultural features of the environment that the male and female students belonged to could be said to have influence on the learning environment. When the patriarchal family structure of the society which included the research sample of the present study was taken into account, it was thought that the male students had a higher level of interaction with the social environment than their female peers. Parallel to this, it was also thought that the negative factors in the learning environments where the male students socially more active in school and class environments than the female students might have had negative influence on general perceptions about courses including physics. Both groups of students participating in the study stated that the teacher's inefficacy in the field and his/her teaching style had negative influence on them. As an important component of the learning environment, a teacher's capability of concretizing the abstract aspects of physics depends on his or her capacity in the field. A qualified teacher, effective teaching style and the methods and techniques applied by the teacher could increase students' attendance in classes. In one study carried out by Mujtaba and Reiss (2012), it was found that teacher's efficacy in teaching physics and interesting activities to be carried out by the teacher in class had positive effects on both male and female students' attendance in physics classes. In this respect, it could be stated that learning approaches that shape the teacher's in-class applications are considered important.

In this study, the analysis conducted to examine the influence of the mathematical aspect of physics courses on the related difficulty experienced by the students did not reveal any significant difference between the male and female students. According to the content analysis results, both the male and female students emphasized the mathematical dimension of the courses of physics. In related literature, not many findings were reported in favor of the female students in studies conducted on the mathematical perceptions of male and female students. For instance, in a study examining the mathematical perceptions of students with respect to gender, Githua (2013) found that female students found mathematics more difficult when compared to male students. In another related study, Nosek et al. (2002) reported that female students had a lower level of attendance in classes in the field of physical mathematics than male students. Mandina and colleagues (2013) stated that most women consider mathematics to be a difficult field. In addition, Lindberg et al. (2010) compiled the studies conducted on performance evaluation in the courses of mathematics with respect to the variable of gender. In their study, the results revealed that male and female students demonstrate similar performance in mathematics. The negative perception regarding mathematics is thought to be an important factor causing individuals to develop bias for the courses of physics. In contrast with the findings reported in related literature, those obtained in the present study could be said to be important as these findings are likely to indicate a decrease in the gender-based differences in negative perceptions regarding scientific fields.

In the present study, the students' views about importance of physics courses, the permanency of what students learned in the courses of physics was examined, and whether the male and female students found the courses of physics enjoyment was investigated. The results did not reveal any significant difference between the male and female students' views. Parallel to the finding related to the importance of physics courses in this study, Veloo and colleagues (2015), in their studies, indicated that there was no difference between female and male students' views about the importance of physics. Moreover, smilar to the findings in this study, Quinn and Lyons (2011) stated that "male and female students in Australia perceived enjoying science to a similar extent." Contrary to this result, in related literatures, it was found that there were differences between female and male students' perceptions of enjoyment in physics courses in favor of the 
male students (Kost, et al., 2009; Reid, 2003). When the male and female students' views were taken into account, it was found that both groups of students found the courses of physics important and entertaining since it includes examples from daily life and that their knowledge about physics they had learned in class was permanent. In the study, it was a striking finding that remarkable numbers of the male and female students considered the courses of physics to be entertaining since it includes mathematical aspects. Contrary to these findings, in related literature, female students are reported that they evaluated science more negatively than males (Hill et. al., 2010; AAUW, 2013; IOP, 2014). Based on this finding, it could be stated that female students, who are not involved in the today's important science of physics at all, actually have the potential to be as successful in the field as male students. It is thought that this potential could be transformed into reality with appropriate methods and techniques. The reason is that in the study, the female students criticized the methods and techniques applied by the teacher in class. In order for especially female students to be involved in the fields of physics, the education given in secondary schools is considered important for the development of tendency towards scientific fields. According to the International Study of Women in Physics, physics attracts mostly female physicists, and they thus decide to study it in high school (Ivie, Cuzjko and Stowe, 2001, cited in Hazari and Potvin, 2005). In addition, both groups of students similarly found the courses of physics boring and too abstract and stated that it included too many formulas. Therefore, they reported that their knowledge about physics they had learned in class would not be permanent. Parallel to this, both groups of students agreed on a more effective teacher and on the use of laboratory-based methods and techniques so that the courses of physics could be made more entertaining and permanent. According to findings from a study "the provision and use of science labs can not only have a positive impact on student participation and interest, but could also help overcome preconceived notions of girls' inability to perform well in science" (Kelley et al., 2013, cited in Unesco, 2015). The student-centered methods and techniques used in government schools in Turkey are not applied appropriately (Baran et. al., 2015; Çiftçi et.al., 2013). As a result, students are prepared mostly for the university placement exam with methods and techniques that make students rather passive (Baran, 2011). As can be understood from the students' views, students are not in the center of the courses of physics, and the teacher applies an ordinary direct style of teaching. This is likely to cause both male and female students - who already have prejudice regarding physics - to find the courses of physics boring. In a study, Saleh (2014) reported that students generally find the courses of physics boring. The researcher considered the cause of this result to be the education system for teaching physics in secondary schools and stated that students thus had low level of motivation for the courses.

\section{Conclusions}

According to the results of the study, it was found that high school students' perception of physics as a difficult subject is not independent of gender, with females reporting the discipline to be more challenging than their male peers. Moreover female high school students taking physics do not report themselves to be less knowledgeable than their male peers in many areas of this discipline and qualitative data indicate that high school students' engagement in physics would increase if the subject was made more relevant, immersed in real-life examples, and - in general - taught more effectively. Based on this findings obtained in the study, it could be stated that in-class applications could be included in the curriculum to make students happy taking the variable of gender into account. In order to remove the prejudices of especially female students regarding the courses of physics, physics lessons should be taught in a way to develop interactions between the students. In in-class activities, teachers could use various activities that appeal to both male and female students, which will then contribute to students' attendance in class and to their participation in lessons. For this purpose, as suggested by the students, laboratories should be used effectively. This will increase the representation of female students in the fields of physics. In this respect, student-centered applications in secondary education institutions should be more frequently inspected. In addition, students' parents, an important factor in terms of the variable of gender, should be in communication with school administrators as well as with teachers. In line with the students' views, the sub-units of Ministry of National Education should organize related seminars both for teachers and parents.

\subsection{Some Suggestions for Future Research}

1. It can be assessed that whether there is an association between female's perception of physics as a "difficult discipline" and their grades/performance in the course.

2. It can be evaluated that how physics is being taught in order to determine whether variance in teaching may account for variance in participant responses.

3. It can be fleshed out the factors that may encourage or dissuade females from pursuing this line of study.

\section{References}

AAUW(2013). Improve girls' and women's opportunities in science, technology, engineering, and math. http://www.aauw.org/files/2013/02/Why-So-Few-Women-in-Science-Technology-Engineering-and-Mathematics.p df 
Aina, J. K. (2013). Instructional materials and improvisation in physics class: Implications for teaching and learning. IOSR Journal of Research \& Method in Education, 2(5), 38-42. http://dx.doi.org/10.9790/7388-0253842

Aina, J. K., \& Philip, Y. J. (2013). Imperative of environment in science learning. Open ScienceJournal of Education, l(1), 1-6. http://dx.doi.org/10.12966/oje.06.06.2013

Aktamiş, H., Çalışkan, S., \& Aktamiş, I. S. (2012). Ortaöğretim öğrencilerinin fizik problemlerini çözmeye yönelik tutumlarının incelenmesi. Mustafa Kemal University Journal of Social Sciences Institute, 9(20), 395-404.

An Institute of Physics (2014). Raising aspirations in physics. A review of research into barriers to stem participation for students from disadvantaged backgrounds. http://www.iop.org/publications/iop/2014/file_64466.pdf

Bamidele, O. M. F. (2001). Promoting Science and Mathematics Education Amongst females in Nigeria. Presented at The NCCE/UNESCO 5-Day Train the Trainer Workshop for The revitalization of science Education in Nigeria.

Baran, M. (2011). Teknoloji ve proje tabanlı öğrenme yaklaşimi destekli düşünme yolculuğu tekniğinin lise 11. sinif ögrencilerinin fizik başarısı ve akademik benlik tasarımına etkisi. Doctoral Dissertation, Dicle University, Diyarbakır, Turkey.

Baran, M., Baran, M., \& Bozkurt, A. (2015). Fen öğretmen adaylarinin proje tabanli öğrenme yaklaşimina yönelik görüşlerinin değerlendirilmesi. http://ejercongress.org/pdf/BildiriKitab\%C4\%B12015.pdf

Bates, S., Donnelly, R., MacPhee, C., Sands, D., Birch, M., \& Walet, N. R. (2013) Gender differences in conceptual understanding of Newtonian mechanics : a UK cross-institution comparison. European Journal of Physics, 34(2), 421. http://dx.doi.org/10.1088/0143-0807/34/2/421

Bayraktar, Ş. (1999). Türkiye'de ortöğretim düzeyinde fen bilimleri öğrenci başarlsındaki cinsiyete dayall farklllkklar. Yök dünya bankasi milli eğitimi geliştirme projesi hizmet öncesi öğretmen eğitimi, Ankara.

Buabeng, I., Ampiah, J. G., \& Quarcoo-Nelson, R. (2012). Senior high school female students' interest in physics as a courses of study at the university level in Ghana, ife psychologia, 20(1).

Çiftçi, S., Sünbül, A. M., \& Köksal, O. (2013). Sınıf öğretmenlerinin yapilandirmaci yaklaşıma göre düzenlenmiş mevcut programa ilişkin yaklaşımlarının ve uygulamalarının eğitim müfettişlerinin görüşlerine göre değerlendirilmesi. Mersin Üniversitesi Eğitim Fakültesi Dergisi, 9(1), 281-295.

Cox, M. (2015). A basic guide for empirical environmental social science. Ecology and Society, 20(1), 63. http://dx.doi.org/10.5751/ES-07400-200163.

Desforges, C., \& Abouchaar, A. (2003).The Impact of Parental involvement, parental support and family education on pupil Achievements and Adjustments. A literature Review. Research Report RR433. http://bgfl.org/bgfl/custom/files_uploaded/uploaded_resources/18617/Desforges.pdf

Githua, B. N. (2013). Secondary School Students' Perceptions Of Mathematics Formative Evaluation And The Perceptions' Relationship To Their Motivation To Learn The Subject By Gender In Nairobi And Rift Valley Provinces, Kenya. Asian Journal Of Social Sciences \& Humanities, 2(1), 174-183.

Hazari, Z., \& Potvin, G. (2005). Views on female under-representation in physics: retraining women or reinventing physics? Electronic Journal of Science Education, 10(1), 1-33.

Hill, C., Corbett, C., \& St. R. A. (2010). Why so few? Women in science, technology, engineering, and mathematics. Washington DC: American Association of University Women. http://www.aauw.org/files/2013/02/Why-So-Few-Women-in-Science-Technology-Engineering-and-Mathematics.p df

Homer, M., Ryder, J., \& Donnelly, J. (2013). Sources of differential participation rates in school science: the impact of curriculum reform. British Educational Research Journal, 39(2), 248-265.

Hsieh, H. F., \& Shannon, S. E. (2005). Three approaches to qualitative content analysis. Qualitative Health Research, 15(9), 1277-1288. http://dx.doi.org/10.1177/1049732305276687

Ivie, R., Cuzjko, R., \& Stowe, K. (2001). Women physicists speak: the 2001 international study of women in physics. American Institute of Physics Report. Available: http://www.aip.org/statistics/trends/gendertrends.html.

Jovanovic, J., \& Dreves, C. (1995). Math, science, and girls: Can we close the gender gap? In Todd, C.M. (Ed.)., School-age connections, 5(2), Urbana, IL: University of Illinois Cooperative Extension Service.

Karataş, Z. (2015). Sosyal Bilimlerde Nitel Araştirma Yöntemleri. Manevi Temelli Sosyal Hizmet Araştırmaları Dergisi, $1(1), 62-80$. 
Keeves, J., \& Kotte, D. (1992). Disparities between the sexes in science education: 1970-84. In J. Keeves (Ed.), The IEA study of science III. New York: Pergamon.

Kelley, T., Plakmeyer, A., Shan, L., Sonnenberg, L., \& Vargas, H. (2013). Science performance among female students: An evaluation of science labs, utilization and teachers' skills and attitudes towards the field of science at CFC schools. Unpublished Evaluation Report cited in Unesco, (2015).

Kessel, U., Rau, M., \& Hannover, B. (2006). What goes well with physics? Measuring and altering the image of science. British Journal of Educational Psychology, 76(4), 761-780. http://dx.doi.org/10.1348/000709905X59961

Kost-Smith, L. E., Pollock, S. J., \& Finkelstein, N. D. (2009). Unpacking gender differences in students' perceived experiences in introductory physics. http://www.colorado.edu/physics/EducationIssues/papers/Kost_etal/Kost_PERC_2009_final_revised.pdf

Kost-Smith, L. E., Pollock, S. J., \& Finkelstein, N. D. (2010). Gender disparities in second-semester college physics: The incremental effects of a "smog of bias" Physical Review Special Topics - Physics Education Research, 6, 020112. http://dx.doi.org/10.1103/PhysRevSTPER.6.020112

Lindberg, S. M., Hyde, J. S., Petersen, J. L., \& Linn, M. C. (2010). New trends in gender and mathematics performance: a meta analysis. Psychological Bulletin, 136(6), 1123-1135. http://dx.doi.org/10.1037/a0021276

Madsen, A., McKagan, S. B., \& Sayre, E. C. (2013). Gender gap on concept inventories in physics: what is consistent, what is inconsistent, and what factors influence the gap? Physical Review Specialtopics-Physics Education Research, 9, 020121. http://dx.doi.org/10.1103/PhysRevSTPER.9.020121

Mallow, J. V. (2010). Gender, science anxiety, and science attitudes: a multinational perspective expert group meeting gender, science and technology Paris, France 28 September - 1 October 2010EGM/ST/2010/EP.5

Mandina, S., Mashingaidze, S. S., \& Mafuta, J. (2013). Increasing female participation in advanced level mathematics: A perspective from students and teachers in Zimbabwe. African Educational Research Journal, 1(3), 183-190.

McKenna, J., D’Iorio, M., McMillan, A. C., \& Svennson, E. C. (2002). Report on the first international Conference on women in physics. La Physique Au Canada, 17-23.

Miles, M. B., \& Huberman, A. M. (1994). Qualitative data analysis, 2nd Ed., p. 10-12. Newbury Park, CA: Sage.

Mujtaba, T., \& Reiss, M. J. (2012). Gender differences in 15 year-olds' perceptions of physics, physics teachers and physics lessons. In: EBook Proceedings of the ESERA 2011 Conference: Science Learning and Citizenship, Catherine Bruguière, C., Tiberghien, A. \& Clément. P. (Eds), Part 11: Cultural, Social and Gender Issues, pp. 27-33. Available at http://lsg.ucy.ac.cy/esera/e_book/base/ebook/ebook-esera2011.pdf

Nosek, B. A., Banaji, M. R., \& Greenwald, A. G. (2002). Math= Male, Me=Female, Therefore Math $\neq$ Me. Journal of Personality and Social Psychology, 83(1), 44-59. http://dx.doi.org/10.1037/0022-3514.83.1.44

Özay, E., Ocak, İ., \& Ocak, G. (2003). Genel biyoloji uygulamalarinda akademik başarı ve kalıcılı̆̆a cinsiyetin etkisi. Pamukkale Üniversitesi Eğitim Fakültesi Dergisi, 2(14), 63-67.

Özgün-Koca, S. A., \& Şen, A. İ. (2011.) Evaluation of beliefs and attitudes of high school students towards science and mathematics courses. Journal of Turkish Science Education, 8(1), 42-60.

Quinn, F., \& Lyons, T. (2011). High school students' perceptions of school science and science career: a critical look at a critical issue. Science Educational Journal, 22(4), 225-238.

Reid, N. (2003). Gender and physics. International Journal of Science Education, 25(4), 509-536. http://dx.doi.org/10.1080/0950069022000017270

Saleh, S. (2014). Malaysian students' motivation towards Physics learning. European Journal of Science and Mathematics Education , 2(4), 223 - 232.

Schunk, D. H., \& Meece, J. L. (2005). Self-efficacy Development in Adolescences. Self-Efficacy Beliefs of Adolescents, 71-96.

Unesco, (2007). Science, technology and gender: an international report. Retrieved from http://unesdoc.unesco.org/images/0015/001540/154045e.pdf

Unesco, (2015). A complex formula. girls and women in science, technology, engineering and mathematics in asia girls and women in science, technology, engineering and mathematic. http://unesdoc.unesco.org/images/0023/002315/231519e.pdf

Veloo, A., Nor, R., \& Khalid, R. (2015). Attitude towards physics and additional mathematics achievement towards 
physics achievement. International Education Studies, 8(3), 35-43. http://dx.doi.org/10.5539/ies.v8n3p35

Visser, Y. L. (2007). Convergence and divergence in children's attitudes toward the sciences and science education. Learning Development Institute, Florida Atlantic University.

Whitten, B. L., Foster, S. R., \& Duncombe, M. L. (2003). What works for women in undergraduate physics? Physics Today, 46-51. http://dx.doi.org/10.1063/1.1620834

This work is licensed under a Creative Commons Attribution 3.0 License. 